Erwin Dirscherl

\title{
The Ethical Significance of the Infinity and Other- ness of God and the Understanding of Man as "Inspired Subject«: Emmanuel Levinas as a Challenge for Christian Theology
}

\section{Etični pomen neskončnosti in drugosti Boga ter razumevanje človeka kot »navdihnjenega subjekta«: Emmanuel Levinas kot izziv za krščansko teologijo}

Abstract: The thinking of $\mathrm{E}$. Levinas deeply influences the actual debates in Christian systematic theology. In catholic thinking, we know the norm of the Lateran Council in 1215: You cannot discern a similarity between God and man without discerning a greater dissimilarity between them. Do we take this norm seriously in our metaphysical ontology and theology? The otherness and goodness of God is the main problem in Levinas' philosophy and with regard to the catastrophes of the two world wars and the Shoa in the twentieth century he asks, what the significance of the talking about God in present times could be. Ethics has to become the "prima philosophia " because all our thinking and acting has an ethical significance and thus we may not forget this. Therefore, infinity and otherness receive an ethical meaning and constitute our responsibility as »inspired subjects « for the whole world. In the tradition of Jewish thinking, Levinas combines the unicity of each man and the universality of human responsibility for all people. In the face of the other, who is suffering, we are confronted with the face of God himself. What can we learn from Levinas today?

Key words: Infinity of God, Otherness, Levinas, Talking about God, Ethics, Anthropology

Povæletek: Misel E. Levinasa v veliki meri zaznamuje sodobne razprave s področja krščanske dogmatične teologije. V katoliški misli poznamo določbo Lateranskega koncila (iz leta 1215), da ne moremo izraziti nobene podobnosti med Bogom in človekom, ne da bi morali ob tem priznati še večjo nepodobnost med njima. Ali to določilo v naši metafizični ontologiji in teologiji jemljemo resno? Drugost in dobrost Boga predstavlja glavni problem v Levinasovi filozofiji in z ozirom na katastrofe obeh svetovnih vojen ter holokavsta v dvajsetem stoletju se Levinas 
sprašuje, kakšen pomen ima lahko govor o Bogu v sodobnem času. Etika mora postati "prva filozofija«, saj ima vse naše mišljenje in delovanje etični pomen, na katerega ne smemo pozabiti. Tako neskončnost kot drugost dobita etični pomen in vzpostavljata našo odgovornost, ki jo kot »navdihnjeni subjekti« nosimo za ves svet. Opirajoč se na tradicijo judovske misli Levinas spaja edinstvenost slehernega človeka in univerzalnost njegove odgovornosti za vse ljudi. Pred obličjem drugega, ki trpi, se nahajamo pred obličjem samega Boga. Česa se lahko naučimo od Levinasa danes?

Ključne besede: Božja neskončnost, drugačnost, Levinas, govor o Bogu, etika, antropologija

The rule of analogous talking about God, which was verbalised in the fourth Lateran Council in 1215, still has an impact on Roman Catholic theology today. "We cannot express a similarity between God and creature without mentioning an even bigger dissimilarity " (DH 806). ${ }^{1}$ That is why in my opinion Levinas is a great thinker, who can teach us Christian theologians to take the rule above more seriously and to incorporate it to a greater extent into our day-to-day business than we sometimes manage in our field of study. How do we cope with the remaining incomprehensibility of the talking about God without jeopardising the significance of biblical speech?

\section{Levinas and the question of the meaning of life: Critical thinking and responsibility in light of the problems of our time}

Emmanuel Levinas' (1906-1995) thinking was strongly influenced by both world wars, Nazi-oppression, and the Shoah?, during which nearly his whole family was extinguished. Biography and thinking belong together. Due to the incomprehensible pain and the mass-murderous extermination of human life, he struggles with the questions of God, man, and the good. This illustrates that the question of theodicy is as dramatically touched as the doctrine of God, anthropology, and ethical philosophy, from a systematic theological point of view.

In the context of a post-Auschwitz theology, which cannot simply go back to day-to-day business after the catastrophe of the Shoah?, Levinas becomes a valuable and essential interlocutor. Not only was he globally received as a philosopher, but as an important advocate of Judeo-Christian dialogue. He was repeatedly invited to Rome by Pope John Paul II and Pope Francis knows about Levinas theories also through the reception of liberation theology.

Levinas was inspired by the Bible of Israel and Hebrew thought. Hebrew thought differs from Greek philosophy and its idea of an immortal soul. It deals with

1 „Quia inter creatorem et creaturam non potest tanta similitudo notari, quin inter eos maior sit dissimilitudo notanda.« (DH 806) 
temporality and physical condition of mortal human beings in an alternative approach. Levinas liked to compare both theories to Abraham and Ulysses. Abraham leaves his secure home and travels to an unknown remoteness without speculating about a return. Likewise, Ulysses leaves his home and experiences many adventures, but other than Abraham, he comes back home after every adventure. He represents the human, who is received as a self-reflective subject, which in a state of self-reflection and self-confidence manages to revert to the Self and to bundle outer influences within. Whereas, in Levinas opinion, Abraham represents the biblical anthropology, in which mankind lives through time and according to God's promise and awaits an open future, as it is promised in the book of Exodus. Levinas sees the passing away of the Self as the incarnate motion of transcendence and as a step to exceed the Self towards God and the neighbour. Mankind is "incarnate consciousness". The body is the organ of transcendence because the flesh becomes the word whenever we share a conversation with others. Through speech we develop a true proximity between each other. I give myself to the other, I ex-pose myself to a full extent, up to a vulnerability and maybe even up to the gift of my life. The relationship to the Other gets deeply under the skin, into the heart and the conscience.

Levinas adopted the phenomenology, which he had learned from M. Heidegger and E. Husserl in Freiburg during his academic studies. His starting point were the dramatic experiences of his times and his questioning their meaning for humanity. Levinas also adopts the question of the meaning of existence by Heidegger. There are countless methods to interpret what happens between two people, but how do we determine the initial meaning? Is the meaning that we are looking for given, or does it only come about through our contemplation? The question of the origin of meaning is what connects Levinas and Husserl. Husserl used the method of reduction to answer the question of the essence of things. He also reached a conclusion about »original impression « (Ur-impression), which is present at the beginning of our experiences and which emphasises the meaning of sensuousness. Levinas talks about a fundamental passivity of mankind, which preceeds the contrast of active and passive, and he connects these thoughts with the question about the creation by God (Dirscherl 2017, 246-252).

\section{The idea of the infinite ethically turned over: universal responsibility}

To Levinas the idea of the infinite in metaphysics is most clearly depicted by the well-known philosopher Descartes. Descartes managed to depict the relationship between the Self and the infinite as a separation (Levinas 1987, 196). Levinas wants to attribute theoretical thinking about existence and the idea of the infinite to a significance which is not based on the light of reason, but still is not irrational and thus is ethically important, by using the phenomenological method. The idea of infinity means the separation of the Self and the Other. This separation 
opens the space »between us « and symbolises a relationship of proximity in independence $(1969,103)$. Furthermore, it constructs the thinking and inwardness of the subject. Accordingly, this relation is characterised by asymmetry. The subject sees itself confronted with an infinity that is not only based on inner thought, but rather refers to an incarnate consciousness, which directly encounters the Other (27-28).

According to Levinas, experience only deserves its name if it exceeds our nature $(1987,185)$. Experience inevitably needs to lead to the Other, to transcendence $(1986,346)$. To encounter otherness excludes any reduction of the Other towards the Self. The idea of the infinite is the only idea which teaches us something that we do not already know.

"The infinite is within us. It is not a memory. We have an experience in the only radical meaning of the word: a relationship with the outer, the Other, without being able to integrate it within the Self. The thinker, who carries the thought of the infinite, is more than just himself, and this inflation and addition does not come from within." $(1987,197)$

Levinas, nevertheless, manages to talk about experience, an experience of the Other in a sense of fundamental passivity. He talks about an experience that cannot acquire the Other and does not manage to integrate it into the horizon of consciousness. The consciousness thinks more than it can (185).

»Experience and the idea of infinite proves itself within a frame of a relationship to the Other. The idea of the infinite is a social relationship « (198). This relation means the approximation to an outer-being. Being on the outside manifests itself in a complete resistance, which the Other, in its epiphany, sets against any capability of the Self. This resistance does not take place in an abstract thinking which achieves to conquer any resistance. The epiphany of the ultimate Other is not a vision of a sensuous or intelligible form in the light of reason, but rather the "no" which is hurled at the capability of the subject.

»Its logos is: >You shalt not kill!« (198) Levinas adopts the Decalogue, the Ten Commandments, and puts the prohibition of killing in focus. This is the ethical resistance between the Self and the Other: You will not have me at your disposal! Levinas also connects this thought with aniconism: You shall not make for yourself an idol of God and of the Other! I cannot imagine an idol of the Other because he is characterised by an incomprehensibility, which exceeds any imagination. To force the Other into an image, which I have visualised of him, forces a violence on him that robs him of his transcendence. The condition of mankind, which represents a transition from the order of being into an order beyond being is sensibility and bodiliness. It is through these that the subject can manage to be "out of itself «. Through these the subject can directly encounter the neighbour as another, from which it receives sense and meaning.

"This, which immediately makes sense, even before it is given to it, that is thy neighbor." (281) This is where the meaning of sensuousness lies: an immediate 
sense can be received through it, which cannot be constructed or deduced from a consciousness of the Self. Significance is received by the Other. The Other does not gain its meaning by the Self, but through himself, which means that he gains an underivable meaning and dignity. This is the exact meaning of the face of the Other. This face is not a phenomenon, but rather "self-importance par excellence« (282). It does neither receive its meaning through the Self, nor by a totality of sense or a system. Levinas follows the thought of unicity (unicité) radically. Every human being is unique, incomparable, individual, and indefensible. Unicity describes an inaccessible and immediate meaning of every person, which is not due to human ascription. No one can deny another's meaning and dignity, like it is the case in totalitarian systems or ideologies, which even want to decide when a human is a human and when humanness is denied. This means killing someone else. According to Levinas the importance of mankind is out of the question. The face of the Self is the source of sense. Its significance is absolute; it is detached from any attribution of meaning by the subject or a system. This cannot be without consequence for the Self and reasoning.

Ethical resistance opens the dimension of infinity, which sets bounds to the compelling imperialism of the Self, which wants to control and design everything. Ethical resistance symbolises the presence of the infinite (199). To the Self it signifies the injustice of its imperialistic thoughts towards the Other.

„That is why the Other is not just another freedom. To know about the injustice means to have a view out of the dimension of the ideal. The Other has to be closer to God than the Self. This is by no means an invention of philosophy, but rather a given fact of moral consciousness, which could be determined as the consciousness of the priority of the Other over the Self. Well perceived justice starts with the Other.« (200)

Levinas once summarised his philosophy very simply: after you, my lady, sir. Aprés vous! The ethical relationship with the Other is the basis and not a superstructure of awareness. The Other precedes me, he is already there when I am born, and I follow him. Others have decided that I should come into existence. Even before I can reflect up it, I am confronted with the Other. That is why the idea of the infinite, in which the conscious thinks more than it actually can, cannot be understood as a matter of contemplation.

Beyond desires (besoin) like hunger and thirst, which can be met, to Levinas there also exists a desire (désir) for the absolute Other, which cannot be met. This desire is unappeasable and thus is witness to the otherness of the Other. The desired cannot be reached. The yearning is about the Other that cannot be coopt. It moves otherness into a sphere of the sublime (201). That is how free will is empowered to benevolence.

»The structure of free-will, which transforms into benevolence, is no longer like the conceited and modest spontaneity of the Self and of luck, which are perceived as outer movements of existence. In relation to this a 
volition which transformed into benevolence is so to speak an inversion. The life of freedom, which in itself discovered to be unjustified, the life of a freedom of heteronomy, only exists within a never-ending movement that constantly doubts itself. That is how the depth of inwardness reveals itself. The growth of high standards that I set for myself accentuates the verdict that I have to endure. This results in responsibility. The intensification of responsibility increases insistence. Within this construct, freedom does not have the last word. I never rediscover myself in loneliness, or, to put it differently, the moral consciousness is unmet, there is always a certain desire." (205)

The subject constantly compares itself to the idea of the infinite, which doubts the self-assertion of the Self, and, thus, always feels a certain feeling of injustice and imperfection. There is a certain feeling of shame, which freedom perceives itself to be because it acts like a usurper. The substitution of freedom represents a moral life, which is bound by diachronic heteronomy. Ethical consciousness precedes freedom. Levinas interprets the dissatisfaction of moral consciousness as a contraction, as a retraction of consciousness in itself, and as a systole of the same. This insinuates the biological and biblical perception of the heart. Levinas conceives creation as a means of giving the Other space and withdrawing oneself. The movement of the idea of the infinite means contraction and this contraction is even more fundamental than the freedom, which opens the environment for it (205). God commands people by putting us in contact with people who require our action (207). This is the only fashion in which Levinas even dares to speak of mediation. Mediation implies that a free person is dedicated to their neighbour and that no one can save themselves without the help of another $(2003,66)$. This is precisely where Levinas draws from the biblical legacy and Jewish tradition.

\section{The trace of the infinite and the human being as an image of God}

The trace of God, who did not expand himself in creation but rather retreated in order to give the world its needed space, disrupts the order of the world. The mystery of transcendence and mankind evolves from this trace. This mystery is the way the ab-solute performs. The traces of God disrupt synchronisation. Also, the traces cave in the idea of the infinite as a symbol of immemorial past. Still existing questionability and mysteriousness shape the existence of humankind, which cannot explain everything in the world, but nevertheless has to act and make decisions.

To leave traces means to pass by, to decamp, to self-absolve, and to let go $(1986,357)$. Levinas interprets transcendence as a passing (passer), as the passing (se passer) of transcendence in an immemorial past (passé). Saying this, Levinas has the passing of God like in Pesach in mind, which the Bible talks about in Exo- 
dus 33. The transcendence of God left its traces. These traces are a bond of the ab-solute Other. They imply the merging of time and space, the point where the world yields to past and future (358). Transcendence happens outside the differentiation of to be and being, as »Ille " and the third person. "Only a being that transcends the world can leave a trace.« (358)

The trace symbolises the presence of him who was not there, of something that has always past. It does not lead to the past, but it is the changing into a past, that is more distant than all the past and all the future which still belong to the presence of the Self, a changing into the past of the Other, in which eternity becomes apparent, the absolute past, that unites all times (358). The movement of the transcendence happens in the face of the neighbour. It is through itself transcendence and affliction, because it is within the trace of the illeity. The illeity is the »origin " of the otherness.

The Self gets closer to the infinite by approaching a "you « that is his contemporary. In the trace of the illeity, however, the you walks up to me from the depths of an uncatchable past. The Self gets closer to the infinite to the same degree as it forgets itself for the neighbour.

»I only forget myself by breaking through the unalterable simultaneity of perception (imagination) by existing beyond my own death. I get closer to infinity by sacrificing myself. The sacrifice is the degree and the norm of the approximation. And the truth of transcendence lies in the fact that speech and action should be reconciled « $(1987,258)$.

The sacrifice symbolises the possibility of self-sacrifice for the Other that can lead up to giving one's own life for the others that happens between ourselves and gives us something to think about. Accordingly, Levinas can understand people's God-likeness.

"The God who passes is not the model of which the face would be an image. To be in the image of God does not mean to be an icon of God, but to find oneself in his trace. The revealed God of our Judeo-Christian personal order itself. He shows himself only by this trace, as is said Exodus 33. To go toward Him is not to follow this trace which is not a sign; it is to go toward the others who stand in the trace of illeity. « $(1986,359)$

The unevenness of the trace lies in the fact that it commends the Self in his longing for the good, for God, to the Other and thus infers a longing onto the neighbour.

In the relationship to the Other, he is not established as an object, his meaning is not set up. It is a matter of the immediate contact/touch to a unicity that attains its distinction not through a system, a universality or a totality, but is attributed meaning of its own accord. The immediacy of the contact does not imply a spatial bordering of one another that would be apparent to a third person, but it is the proximity itself that attributes meaning of its own accord $(1987,274)$. Due to the proxi- 
mity, the intentional turns into ethics. The ethical signifies a turn of subjectivity. The subjectivity that is open for the entities for the purpose of perception, turns back into a subjectivity that comes into contact with an ab-solute and unconceivable singularity which excludes every thematization, imagination or comparison.

»Here we have the original language, the foundation of the other languages. Where this transition of the intentional into the ethical takes place and does not cease to take place, where the approaching breaks through consciousness - where that happens, right there is skin and human face. The touch means tenderness and responsibility." (275) Levinas thinks of language as a contact of incarnate subjects, in which the touch breaks through consciousness in its intentionality. Solely because of that it can be spoken of immediate proximity, that it not mediated through consciousness or its imagination or first and foremost could be set up by it. It is not surprising that Levinas refers to the immediacy of the sensual and brings it to mind as an incident of proximity. The immediacy of the sensual consists of the fact that the sensual touch in the proximity cannot be attributed to an experience of proximity. The example of the caress, becoming apparent with physical touch, without changing its meaning into an experience of caress, thus illustrates the immediacy of the proximity without intention.

"This relationship of proximity, this contact that cannot be converted into noetic-noematic structures and that already is the wherein for all transmissions of messages $/ . . . /$, is the original language, language without words or sentences, pure communication. " (280) In a language understood just like that, the other immediately holds meaning, before it is given to him. The immediacy arises from the proximity that the Self is exposed to. The proximity between the separated skips consciousness - not due to a lack but due to a surplus of proximity. The surplus of proximity means that it always has an anachronistic presence in relation to consciousness. Only in hindsight we can catch the meaning of the presence that has passed just now and that we can only interpret later. Consciousness is always late when having a rendezvous with the neighbour, it chases after an absolutely elusive meaning that it has not constituted itself. The neighbour is not made to measure consciousness (282). With reference to consciousness as a passive work of time, as passivity that is more passive than all passivity - like the passivity of the creature during the Creation - Levinas ascertains that such consciousness cannot be characterised with categories of intentionality (271). It rather means that human speech occurs as proximity and touch. In the speech, the Other is not made the subject of discussion but he is approached (1981b, 61-85).

»The speech and its logical workings were thus not rooted in the Other ss understanding but remained in his proximity. Not being able to elaborate on any subject, not splitting itself up into images, not being able to appear - the invisibility, is it due to the meaninglessness of existence or due to the surplus meaning that exceeds the meaning that obtains its light from the existence of the being? « $(1987,274)$ 
The proximity of the other means a break in the presence, absence in the presence, a presence that cannot be envisioned as proximity of the Other who is the ab-solute, the ab-sent whom consciousness cannot envision. Here the biblical tension of God's immanence and transcendence appears. The Self cannot make up the surplus meaning of the Other, in which infinity announces itself. A relationship without simultaneity, dia-chrony (1998b, 107-108). The presence of the other receives its order from the non-place, from the absence in which the infinite advances. Its order is based on the trace of its own progress and is organised according to my love and my responsibility.

Speech stands for a sign that is given to the Other nearby. The Self itself turns into a sign (signi-fiance) for the Other. Language as fraternity means responsibility for the other and hence responsibility for what I have not committed, also for the pain and the mistakes of the others. The subject is responsible for everyone. Levinas develops a messianic conception of responsibility (1998a, 60). What someone does can be meaningful for everyone and change the world. The messianism starts with myself (Esterbauer 1996, 70-73), with me as a vulnerable human being, capable of suffering (Levinas 1992, 93). The proximity of the infinite symbolises responsibility. It symbolises endless passivity and the inability to withdraw oneself from one's responsibility and desertedness, in which infinity symbolises absence. I am subjected to the Other, an ex-posed existence. This is my election (Dausner 2016, 119-138; Dirscherl 1996, 462-480).

\section{The incarnated and inspired subject}

According to Levinas the body and not consciousness turns into an organ of transcendence, the sensuousness turns into a place where meaning is received. Transcendence can only occur in the physical act and not in mere imagination. Through the body, the Self is responsible for the world, the passivity of being incarnated implies a responsibility that I am appointed to before every relationship that I can choose freely. The freedom arises from a responsibility and a choice that in a diachronic sense precedes the freedom. I cannot escape this responsibility, I cannot make excuses if the Other is commended to me and needs my help. The responsibility signifies freedom.

»Here what is due goes beyond having but makes giving possible. This recurrence is incarnation. In it the body which makes giving possibly makes one other without alienating. For this other is the heart, and the goodness, of the same, the inspiration or the very psyche in the soul." (Levinas 1981a, 109)

The words »inspiration « and "psychism« are chosen deliberately. The phenomena of air and breathing are of outstanding importance for Levinas. Phenomenologically, this, for one thing, is once again illustrated through speech. For when what is said is traced back (re-duced) to speech, what is said is thus traced back to breathing (181). The breath of speech opens me up to the Other. Speech sym- 
bolises the only way in which the incarnated Self and the Other can immediately come close to each other without using violence. In Hebrew, the word "Ruah" that is often translated with "mind " actually means breath, air, or wind. Levinas adopts this biblical context. The openness of the Self for the Other signifies a relationship that does not imply to arrange oneself, but to breath. The first human being in the book of Genesis is given respiration by God, he is inspired, and transcendence takes place as de-termination (181-182). It means "To open oneself as space, to free oneself by breathing from closure in oneself« (180).

Levinas speaks of the "psychism of the soul " that is understood as the phase shifting of human identity, as the Other within me. The time in which I meet the other is expanded between the I and the Self. Time and otherness happen within me, in my dynamic identity. The sincarnated ability to benevolence " derives from the Other and »is extended to become physically tangible benevolence (Sirovátka $2006,197)$. Without this heteronomy, Levinas cannot envision freedom as responsibility. The subject is not identical to himself. The discrepancy within himself symbolises the temporal relationship to the Other that is lived in the flesh and was opened by the Other and by the infinite in an immemorial past: creation. This is how incarnate transcendence can happen for the Other in existence which implies a nuclear fusion of the Self. This, however, requires a world beyond, my inspiration through the Other. Closeness of the Other means inspiration to the end, to breathing one's last breath if death is coming. This takes a long breath, it takes great persistence. Mind signifies having the longest breath possible (Levinas 1981a, 181-182).

Within himself, deep-down, the Self is physically and placelessly exposed to this Other. According to Levinas, this exposedness at the same time signifies being appointed as a subject in freedom and responsibility. The Self's path to the Self leads through a time in which I encounter the other as someone who is destitute and challenging, whether I like it or not. The Self's immediate meaning is owed to something that is "beyond existence", the infinity. "The glory of Infinite is the anarchic identity of the subject flushed out without being able to slip away. It is the ego led to sincerity, making signs to the other, for whom and before whom I am responsible, of this very giving of signs, that is, of this responsibility: shere I amı." (144-145)

The Self's identity signifies bearing physically witness of the glory of the infinite: in-fini in the double meaning of »in the finite» and »infinite». According to Levinas, God's revelation occurs through the person that receives it, through the inspired subject. Levinas once referred to the Gospel according to Matthew (Mt $25)$ to emphasise his case in the Judeo-Christian context:

॥I would say, yes, insofar as I say that the relation to the other is the beginning of the intelligible. I cannot describe the relation to God without speaking of my concern for the the other. When I speak to a Christian, I always quote Matthew 25; the relation to God is presented there as a relation to another person. It is not a metaphor: in the other, there is a real presence of God. In my relation to the other, I hear the Word of God. It is 
not a metaphor; it is not only extremely important, it is literally true. I'm not saying that the other is God, but that in his or her Face I hear the Word of God.« (1998a, 109-110)

And that signifies according to Levinas' ethics: the immediate vision of the Other's epiphany, without mediation (1990, 47-48).

The dialogue with E. Levinas' thought can help theology to take the analogous talking of God, that I mentioned at the beginning of my paper, more seriously, to respect its all the more greater dissimilarity and incomprehensibility, and understand analogy as correspondence (Casper 1989, 219-223); to fulfil the word of God in the light of the Other by taking over our prophetic and messianic responsibility for the purpose of charity: Here look at me, you have got me here!

\section{References}

Casper, Bernd. 1989. Analogie, Ein Hinweis auf die Möglichkeit, sie zeitlich zu denken. In: Der Weg zum Menschen: Zur philosophieschen und theologischen Anthropologie FS A. Deissler, 219-233. Ed. Mosis Rudolf, and Ruppert Lothar. Freiburg: Herder.

Dausner, Réné. 2016. Christologie in messianischer Perspektive: Zur Bedeutung Jesu im Diskurs mit Emmanuel Levinas und Giorgio Agamben. Paderborn: Ferdinand Schöningh.

Dirscherl, Erwin. 1996. Die Bedeutung der Nähe Gottes: Ein Gespräch mit Karl Rahner und Emmanuel Levinas. Würzburg: Echter.

- - - 2017. Emmanuel Levinas. In: Kleine Philosohpiegeschichte: Eine Einführung für das Theologiestudium, 246-252. Ed. Breul Martin, and Langenfeld Aaron. Paderborn: Ferdinand Schöningh.

Esterbauer, Reinhold. 1996. Verlorene Zeit - wider eine Einheitswissenschaft von Natur und Gott. Stuttgart et al.: Kohlhammer.

Levinas, Emmanuel. 1969. Totality and Infinity. Translated by Alphonso Lingis. Pittsburgh: Duquesne University Press.

- - . 1981a. Otherwise than Being or Beyond Essence. Translated by Alphonso Lingis. The Hague: Martinus Nijhoff.

- - - 1981b. Dialog. In: Christlicher Glaube in moderner Gesellschaft, 61-85. Ed. Böckle Franz et al. Freiburg: Herder.
- - - 1986. »The Trace of the Other«. Translated by Alphonso Lingis. In: Deconstruction in Context, 345-359. Ed. Talyor Mark. Chicago: University of Chicago Press.

-- -. 1987. Die Spur des Anderen: Untersuchungen zur Phänomenologie und Sozialphilosophie. Translated by Wolfgang Nikolaus Krewani. Freiburg and München: Karl Alber.

- - . 1990. Nine Talmudic Readings. Translated by Anette Acronowicz. Bloominton, Indiana: Indiana University Press.

- - - 1992. Schwierige Freiheit: Versuch über das Judnetum. Frankfurt am Main: Jüdischer Verlag.

- - - 1998a. On Thinking of the Other »entre nous «. Translated by Michael B. Smith and Harshav Barbara. New York: Columbia UP.

- - . 1998b. Of God Who Comes to Mind. Translated by Bettina Bergo. Palo Alto: Stanfrod University Press.

- - - 2003. Humanism and the Other. Translated by Nidra Poller. Champaign, Illinois: University of Illinois Press.

Sirovátka, Jakub. 2006. Der Leib im Denken von Emmanuel Levinas. Freiburg and München: Alber. 